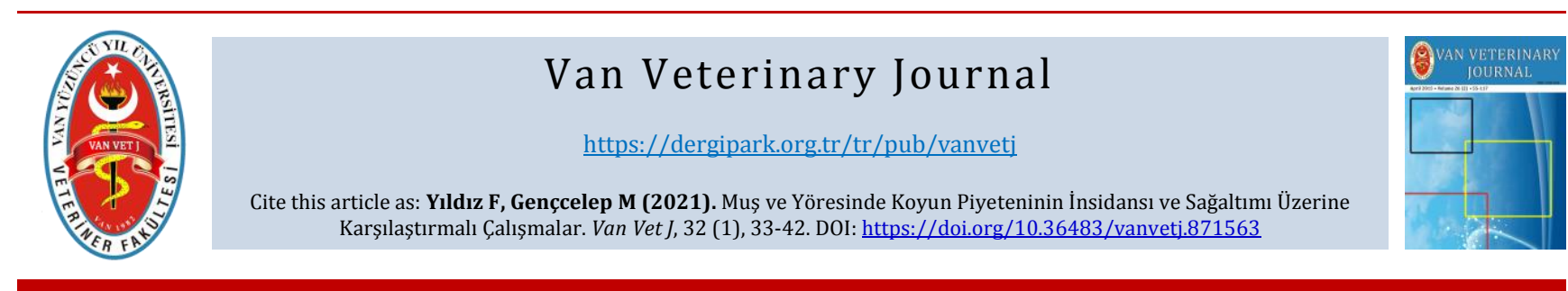

ISSN: 2149-3359

Original Article

e-ISSN: $2149-8644$

\title{
Comparative Studies on the Treatment and Incidence of Footrot in Sheep in Muş and Its Region
}

\author{
Ferit YILDIZ ${ }^{1, *}$ *i] Musa GENÇCELEP2] \\ ${ }^{1}$ Ministry of Agriculture and Forestry, Provincial Directorate of Mus, 49100, Mus, Turkey \\ ${ }^{2}$ University of Van Yuzuncu Yil, Faculty of Veterinary Medicine, Department of Surgery, 65040, Van, Turkey \\ Received: 31.01 .2021 \\ Accepted: 01.03.2021
}

ABSTRACT In the present study, in 2016-2017 years, a total of 10604 animals including 6031 Morkaraman and 4573 Akkaraman sheep were examined. It was determined that 969 of them had footrot disease and the disease was present in flocks with a rate of $9.14 \%$. According to race-age-sex, percentage calculations were done. It was observed that Morkaraman sheep were more resistant to footrot compared to Akkaraman sheep $(\% 8.47<\% 10.02)$ according to the race base. $\mathrm{Ca}, \mathrm{P}, \mathrm{Zn}$ and $\mathrm{Cu}$ elements and their amounts were correlated with each other in the blood serums of the diseased and healthy animals and depending on the disease it was recorded that there was an increase in the value of copper, but a decrease in the value of zinc. In this study, animals were divided into five groups to compare the effects of treatments. The group I was treated with Ceftiofur+Flunixin-meglumine, the group II with $10 \%$ copper sulphate $\left(\mathrm{CuSO}_{4}\right)+$ Flunixin-meglumine, the group III with only $10 \% \mathrm{CuSO}_{4}$ while the group IV was the control group having no treatment. On the other hand, Group V was given vaccination. Whereas the best treatment was provided in group I (90\%); the recovery rate was $60 \%$ in the group II and $20 \%$ in the group III. An improvement of $10 \%$ was achieved in the group IV without treatment. Therefore, it can be inferred that the foot bathing of $10 \% \mathrm{CuSO}_{4}$ isn't enough to treat the disease considering the labor, time and expenses. The treatment must be continued with an antibiotic agent. The efficiency of a parenteral Ceftiofur active antibiotic which doesn't pass into milk, with an anti-inflammatory Flunixin-meglumine on treating the disease in a short time is thought to benefit the breeders in many ways in the treatment of the footrot due to easy access to the medicine and application of it by the breeders with peace of mind. In Group V, successful results were obtained from vaccine application. However, application of $10 \% \mathrm{CuSO}_{4}$ could be considered as a preventive measure for the prevention of the disease.

Keywords: Foot diseases, Footrot, Incidence, Sheep, Treatment

\section{Muş ve Yöresinde Koyun Piyeteninin İnsidansı ve Sağaltımı Üzerine Karşılaştırmalı Çalışmalar}

Sunulan çalışmada 2016-2017 yıllarında sahada 6031 baş Morkaraman ve 4573 baş Akkaraman ırkı koyun olmak üzere toplam 10604 hayvan incelenmiştir. Bunların 969'unun piyetenli olduğu, dolayısıyla \%9.14'lük bir oranla hastalığın sürülerde bulunduğu saptanmıștır. Irk-yaş-cinsiyete göre piyetenin yüzde hesaplamaları yapılmış olup, ırk bazında yüzde oranlar değerlendirildiğinde Morkaramanların Akkaramanlara oranla piyetene daha dayanıklı oldukları görülmüștür $(\% 8.47<\% 10.02)$. Piyetenli ve sağlıklı hayvanların kan serumlarında $\mathrm{Ca}, \mathrm{P}, \mathrm{Zn}$ ve $\mathrm{Cu}$ elementlerinin miktarları ve birbirleriyle korelasyonu yapılmıș ve hastalığa bağlı olarak piyetenlilerde bakır değerinde yükselme buna karşın çinko değerinde azalma görülmüştür. Çalışmada sağaltım karşılaştırmaları için hayvanlar beș gruba ayrılarak I. gruba Ceftiofur+Fluniksin-meglumin, II. gruba \%10'luk bakır sülfat $\left(\mathrm{CuSO}_{4}\right)+$ Fluniksin-meglumin, III. gruba sadece $\% 10^{\prime}$ luk $\mathrm{CuSO}_{4}$ uygulanmıştır. IV. grup kontrol grubu olup herhangi bir tedavi uygulanmamıștır. V. gruba ise aşı uygulaması yapılmışırı. Çalışmada en iyi tedavi I. grupta sağlanırken (\%90), II. grupta \%60, III. grupta \%20, IV. grupta tedavi yapılmaksızın \%10'luk bir iyileşme sağlanmıştır. Dolayısıyla $\% 10$ 'luk $\mathrm{CuSO}_{4}$ ayak banyosunun harcanan emek, zaman ve masraflar göz önüne alındığında hastalığı tedavi etmede yeterli olmadığı, mutlaka antibiyotik bir ajanla tedavinin sürdürülmesi gerektiği anlaşılmıştır. Süte geçmeyen Ceftiofur etken maddeli parenteral bir antibiyotik ile yangı giderici Fluniksin-meglumin kullanıldığında hastalığı kısa sürede tedavi etme yetkinliği, yetiștiriciler tarafından kolay temin edilebilir ve gönül rahatllğıyla uygulanabilir olması sebebiyle piyetenin tedavisinde yetiștiricilere birçok yönden fayda sağlayacağı kanaati oluşmuștur. V. grupta hastalıktan korunmak amacıyla aşı uygulamasından başarılı sonuçlar alınmıştır. Bununla beraber \%10'luk $\mathrm{CuSO}_{4}$ uygulanmasının hastalıktan korunmada önleyici bir tedbir olarak değerlendirilebileceği düşünülmektedir.

Anahtar Kelimeler: Ayak hastalıkları, Insidans, Koyun, Piyeten, Tedavi 


\section{GíRIŞ}

Koyun yetiştiriciliğinin yapıldığı birçok ülkede koyunların en sık rastlanan ayak hastalığı piyeten olarak kabul edilir. Piyetenin ayak hastalıkları arasında birçok ülkede hep ilk sırada olmasının nedeni, bulaşıcı bir enfeksiyon olmasının yanında önemli sayılabilecek verim kayıplarına yol açmasıdır (Alkan 1998; Sağlıyan ve ark. 2003; Sertkaya ve Şındak 2004). Piyeten daha çok ılıman iklim hastalığı olup etkenlerin sağlıklı hayvanlara bulaşması için ılık ve nemli çevre koşulları gerekmektedir (Alkan 1998; Avki ve ark. 2004).

Piyeten interdigital deri, corium ungulae ve diğer dokularda yangı ve nekroz oluşumu ile karakterizedir. Hastalık, capsula ungulae'nin değişik düzeylerde canlı tırnaktan ayrılması ve corium ungulae'nin nekrozu ile karakterizedir (Yavru ve ark. 1989; İzci ve ark. 1994; Alkan 1998). Hastalık çoğunlukla ön ayaklara yerleşir. Özellikle ilkbaharda nisandan hazirana ve sonbaharda eylülden ekime kadar olan dönemde görülür (Yavru ve ark. 1989; İzci ve ark. 1994; Bagley 1998; Sağllyan ve ark. 2003; Sertkaya ve Şındak 2004).

$\mathrm{Bu}$ çalışma planlanırken yapılan ön araștırmada Muş'ta özellikle küçükbaşların en önemli ayak hastalığı olan piyetenin sık sık görüldüğü ancak tedavisinin yetiştiriciler tarafından iyi bilinmediği gözlemlenmiştir. Bu çalışma ile; Muş ili ve yöresindeki koyunlarda piyetenin insidansının belirlenmesi, kan serumlarındaki $\mathrm{Ca}, \mathrm{P}, \mathrm{Zn}$ ve $\mathrm{Cu}$ elementlerinin hastalığın oluşumundaki etkisi ve hastalıktan korunmada aşı uygulamasının etkili olup olmadığının tespiti ile farklı tedavi seçeneklerinin başarı durumları karşılaştırılmıştır. Böylece yetiştiricilerin bu hastalığı daha iyi tanıyıp, hastalığa karşı önlem almaları sağlanacak, minimum zarar maksimum fayda sağlayacak yöntem ve gereçlerle hayvan sağlı̆̆l, hayvan refahı, gıda güvenliği ve halk sağlı̆̆ gözetilerek yetiştiricilerin üretimlerine katkı sağlamak amaçlanmıştır.

\section{MATERYAL ve METOT}

\section{Hayvan Materyali}

Muş ve yöresinde 14 farklı yerleşim yerindeki toplam 47 koyun sürüsünden 10604 baş koyun hayvan materyalimizi oluşturmaktadır. Çalıșmaya dâhil olan sürülerdeki piyetenli ve sağlıklı hayvanların sayıları, oranları, yerleşim yeri, ırk-yaş-cinsiyet dağılım tabloları hazırlanarak hastalığın insidansı belirlenmiştir. Çalışmada 40 baş piyetenli koyunla tedavi grupları oluşturulmuş, 230 baş koyuna aşı uygulaması yapılmıș ve 20 baş sağlıklı koyun ile 20 baş piyetenli koyundan da kan numunesi alınarak iz element tahlilleri yapılmıştır. Gıda, Tarım ve Hayvancılık Bakanlığının 12.12.2017 tarih ve E.3150874 sayılı yazısı ile çalışmanın etik kurul onay belgesine gerek olmadığ belirtilmiştir.

\section{Metot}

Çalışmaya dâhil olan koyunlar mera öncesi dönemde (nisan-mayıs-haziran aylarında) ve mera sonrası dönemde (eylül-ekim-kasım aylarında) piyeten hastalı̆̆ı yönünden alınan anamnez ve klinik muayeneler sonucunda belirlenmiştir. $\mathrm{Bu}$ çalışmada hayvanlar beș gruba ayrılmıștır (grup I, II, III, IV ve V). İlk dört grubun hayvanları piyetenli 40 baş koyunun her grupta $10^{\prime}$ ar adet olacak şekilde eşit paylaşımı yapılarak oluşturulmuştur. Seçilen hayvanların sürü içerisinde kolaylıkla bulunabilmesi için baș, sırt ve kuyruk kısımları farklı renklerde boyanmıştır. V. grubu oluşturan 230 hayvana ise sadece aşı uygulaması yapılmıştır.
Topallığın sınıflandırmasında Samsar ve ark. (1996) tarafından aşağıda ifade edilen sınıflandırma kullanılmıștır.

Hafif Derecede Topallık: Topallık belli belirsizdir.

Orta Derecede Topallık: Dururken pek dikkati çeken bir anormallik bulunmayıp, yürüyüște ve tırıs koșturmada az çok belirgin bir fonksiyon bozukluğu görülür.

Şiddetli (ileri) Derecede Topallık: Hayvan hasta ayağı üzerine hiç basamaz veya bu ayak yerde sürünür. Hareket daha çok üç bacak üzerinde ve sekerek yapılır.

Gruplara aşağıda belirtilen tedaviler uygulanarak kontrolleri yapılmış ve sonuçları tablolara işlenmiştir.

I. grup: Ceftiofur $(1 \mathrm{ml}$ 'de $50 \mathrm{mg}$ ceftiofura eşdeğer ceftiofurhidroklorid $-1 \mathrm{mg} / \mathrm{kg}$ dozda sc yolla 24 saat arayla 2 uygulama $)+$ Fluniksin-meglumin (1 ml'de $50 \mathrm{mg}$ Fluniksin-meglumin- $2.5 \mathrm{mg} / \mathrm{kg}$ dozda im. yolla 24 saat arayla 2 uygulama) uygulanmıștır. İlk uygulamadan sonra her gün kontrolleri yapılarak sonuçları Tablo 1'e işlenmiştir.

II. grup: \%10'luk $\mathrm{CuSO}_{4}(3-5 \mathrm{dk}$ ayak banyosu 24 saat arayla 4 uygulama $)+$ Fluniksin-meglumin $(1 \mathrm{ml}$ 'de $50 \mathrm{mg}$ Fluniksin-meglumin- $2.5 \mathrm{mg} / \mathrm{kg}$ dozda im. yolla 24 saat arayla 2 uygulama) uygulanmıştır. İlk uygulamadan sonra her gün kontrolleri yapılarak sonuçları Tablo 2'ye işlenmiştir.

III. grup: Sadece \%10'luk $\mathrm{CuSO}_{4}$ (3-5 dk ayak banyosu 24 saat arayla 4 uygulama) uygulanmıștır. İlk uygulamadan sonra her gün kontrolleri yapılarak sonuçları Tablo 3'e işlenmiştir.

IV. grup: Kontrol grubu olup herhangi bir tedavi uygulanmamıștır. Bu grubun da her gün kontrolleri yapılarak sonuçları Tablo 4'e işlenmiştir.

V. grup: Aşı uygulanan 230 baş koyundan oluşan gruptur. Koyunların kulağının 5-7 cm gerisinden boyuna derialtı yolla $1 \mathrm{ml}$ aşı enjeksiyonu yapılarak, 4-6 hafta sonra rapel uygulaması ve altı ay sonra üçüncü bir uygulama yapılmış olup, yll boyunca hayvanlar 2-3 hafta arayla kontrol edilmiştir

Gruplara yukarıda belirtilen tedaviler uygulanarak her 24 saatte bir topallığın geçip geçmediği ve hastalığın iyileşme süreci kontrol edilmiștir. Topallık devam ediyorsa hafiforta-şiddetli şeklinde sınıflamaları yapılarak 96 saatin sonundaki durumu da değerlendirilmiş ve tablolara işlenmiştir (Tablo 1-4).

\section{Kan Örneklerinin Analizi}

Piyetenli ve sağlıklı 20'şer hayvanın kan serumlarının analizleri Van Yüzüncü Yıl Üniversitesi Tıp Fakültesi Biyokimya Laboratuvarında yapılmıștır. Cu ve $\mathrm{Zn}$ düzeyleri Atomik Absorbsiyon Spectrofotometresi (AA7000Shimadzu, Kyoto, Japan) ile Ca ve $\mathrm{P}$ düzeyleri ise Abbott Architect (C8000 seri model) cihazlarla çalışılmıștır. Kandaki Ca, $\mathrm{P}, \mathrm{Zn}$ ve $\mathrm{Cu}$ miktarlarının hastalıklı ve sağlam hayvanlardaki değerleri Tablo 5'e işlenmiştir.

\section{Histopatolojik Analiz}

Hastalı̆̆ın histopatolojisini ve hangi dokulara kadar ulaştığını tespit etmek amacıyla piyetenli ayak numuneleri Van Yüzüncü Yıl Üniversitesi Veteriner Fakültesi Patoloji Anabilim dalı laboratuvarında incelendi. Makroskobik incelemesi sonrasında özellikle interdigital bölgede ülseratif dermatitis belirlenen kısımlarından doku örnekleri alındı. Doku örnekleri \%10'luk tamponlu formalin solüsyonunda tespit edildikten sonra rutin takip işlemleri yapılarak parafin bloklara gömülmüş ve mikrotomla $5 \mu \mathrm{m}^{\prime}$ lik kesitler alınarak histopatolojik incelemeler için hematoksilen eozin ile boyanmıștır. 
Tablo 1. I. grup, Ceftiofur+Fluniksin-meglumin uygulanmış grupta topallık derecelendirmesi.

Table 1. Group I, lameness scores in the Ceftiofur+Flunixin-meglumine treated group.

\begin{tabular}{|c|c|c|c|c|c|c|c|c|c|c|}
\hline \multirow{2}{*}{ Sira } & \multirow{2}{*}{$\begin{array}{l}\text { Küpe no: } \\
\text { TR49 }\end{array}$} & \multirow{2}{*}{ Cinsiyet } & \multirow{2}{*}{ Irk } & \multirow{2}{*}{ Yaş } & \multirow{2}{*}{$\begin{array}{c}\text { Topallayan } \\
\text { ayak }\end{array}$} & \multicolumn{5}{|c|}{ Topallık derecesi } \\
\hline & & & & & & Uyg öncesi & 24. saat & 48. saat & 72. saat & 96. saat \\
\hline 1 & 2157060 & Dişi & Akkaraman & 4 Yll & Ön sol & Şiddetli & Orta & Hafif & Hafif & Hafif \\
\hline 2 & 1573019 & Dişi & Morkaraman & 5 Yll & Arka sol & Şiddetli & Hafif & Yok & Yok & Yok \\
\hline 3 & 1573067 & Dişi & Akkaraman & 5 Yll & Ön sol & Şiddetli & Yok & Yok & Yok & Yok \\
\hline 4 & 1573074 & Dişi & Morkaraman & 4 Yll & Arka sol & Orta & Yok & Yok & Yok & Yok \\
\hline 5 & 2155487 & Dişi & Akkaraman & $1 \mathrm{Yll}$ & Ön sağ & Orta & Yok & Yok & Yok & Yok \\
\hline 6 & 2157028 & Dişi & Akkaraman & 3 Yll & Ön sağ & Orta & Yok & Yok & Yok & Yok \\
\hline 7 & 2157068 & Dişi & Akkaraman & 4 Yll & İki ön & Şiddetli & Yok & Yok & Yok & Yok \\
\hline 8 & 1573218 & Dişi & Akkaraman & 4 Yll & Ön sağ & Orta & Hafif & Yok & Yok & Yok \\
\hline 9 & 1318135 & Dişi & Akkaraman & 2 Yll & İki ön & Şiddetli & Yok & Yok & Yok & Yok \\
\hline 10 & 1318085 & Dişi & Akkaraman & 4 Yll & Ön sağ & Orta & Yok & Yok & Yok & Yok \\
\hline
\end{tabular}

Tablo 2. II. grup, \%10'luk $\mathrm{CuSO}_{4}+$ Fluniksin-meglumin uygulanmış grupta topallık derecelendirmesi.

Table 2. Group II, lameness scores in the $10 \% \mathrm{CuSO}_{4}+$ Flunixin-meglumine treated group.

\begin{tabular}{|c|c|c|c|c|c|c|c|c|c|c|}
\hline \multirow{2}{*}{ Sira } & \multirow{2}{*}{$\begin{array}{l}\text { Küpe no: } \\
\text { TR49 }\end{array}$} & \multirow{2}{*}{ Cinsiyet } & \multirow{2}{*}{ Irk } & \multirow{2}{*}{ Yaş } & \multirow{2}{*}{$\begin{array}{c}\text { Topallayan } \\
\text { ayak }\end{array}$} & \multicolumn{5}{|c|}{ Topallık derecesi } \\
\hline & & & & & & Uyg öncesi & 24. saat & 48. saat & 72. saat & 96. saat \\
\hline 1 & 2157024 & Dişi & Morkaraman & 1 Yil & Ön sağ & Orta & Yok & Yok & Yok & Yok \\
\hline 2 & Küpesiz & Erkek & Morkaraman & $4 \mathrm{Ay}$ & İki ön & Şiddetli & Yok & Yok & Yok & Yok \\
\hline 3 & Küpesiz & Erkek & Morkaraman & $4 \mathrm{Ay}$ & Ön sol & Şiddetli & Şiddetli & Şiddetli & Hafif & Hafif \\
\hline 4 & 2155495 & Dişi & Akkaraman & 4 Yll & Ön sağ & Orta & Yok & Yok & Yok & Yok \\
\hline 5 & Küpesiz & Erkek & Morkaraman & 1 Yil & Arka sol & Orta & Yok & Yok & Hafif & Hafif \\
\hline 6 & 1573158 & Dişi & Morkaraman & 4 Yil & Ön sağ & Şiddetli & Hafif & Hafif & Yok & Yok \\
\hline 7 & Küpesiz & Dişi & Morkaraman & 4 Ay & Ön sağ & Şiddetli & Şiddetli & Şiddetli & Yok & Yok \\
\hline 8 & Küpesiz & Dişi & Morkaraman & $4 \mathrm{Ay}$ & İki ön & Şiddetli & Şiddetli & Şiddetli & Şiddetli & Şiddetli \\
\hline 9 & Küpesiz & Erkek & Akkaraman & 2 Yll & Ön sağ & Şiddetli & Şiddetli & Yok & Şiddetli & Şiddetli \\
\hline 10 & Küpesiz & Erkek & Akkaraman & 2 Yll & Arka sol & Orta & Orta & Yok & Yok & Yok \\
\hline
\end{tabular}

Tablo 3. III. grup, sadece \%10'luk $\mathrm{CuSO}_{4}$ uygulanmış grupta topallık derecelendirmesi.

Table 3. Group III, lameness scores in the only $10 \% \mathrm{CuSO}_{4}$ treated group.

\begin{tabular}{|c|c|c|c|c|c|c|c|c|c|c|}
\hline \multirow{2}{*}{ Sira } & \multirow{2}{*}{$\begin{array}{l}\text { Küpe no: } \\
\text { TR49 }\end{array}$} & \multirow{2}{*}{ Cinsiyet } & \multirow{2}{*}{ Irk } & \multirow{2}{*}{ Yaş } & \multirow{2}{*}{$\begin{array}{c}\text { Topallayan } \\
\text { ayak }\end{array}$} & \multicolumn{5}{|c|}{ Topallık derecesi } \\
\hline & & & & & & Uyg öncesi & 24. saat & 48. saat & 72. saat & 96. saat \\
\hline 1 & 2155423 & Dişi & Akkaraman & 5 Yll & Ön sağ & Orta & Orta & Hafif & Hafif & Hafif \\
\hline 2 & 2155386 & Dişi & Akkaraman & 4 Yll & Arka sağ & Orta & Orta & Orta & Orta & Orta \\
\hline 3 & 2155407 & Dişi & Akkaraman & 5 Yll & Arka sağ & Şiddetli & Şiddetli & Şiddetli & Şiddetli & Şiddetli \\
\hline 4 & 1678810 & Dişi & Akkaraman & 4 Yll & Ön sağ & Şiddetli & Şiddetli & Şiddetli & Şiddetli & Şiddetli \\
\hline 5 & 1392980 & Dişi & Morkaraman & 4 Yll & Ön sağ & Orta & Orta & Orta & Orta & Orta \\
\hline 6 & 2155458 & Dişi & Akkaraman & 1,5 Yll & Arka sol & Orta & Orta & Orta & Orta & Orta \\
\hline 7 & 2155406 & Dişi & Akkaraman & 4 Yll & Arka sağ & Şiddetli & Şiddetli & Şiddetli & Hafif & Hafif \\
\hline 8 & 2155409 & Dişi & Akkaraman & 3 Yll & Arka sağ & Orta & Orta & Orta & Orta & Orta \\
\hline 9 & 2155389 & Dişi & Akkaraman & 4 Yll & İki arka & Şiddetli & Şiddetli & Şiddetli & Yok & Yok \\
\hline 10 & 1678769 & Dişi & Akkaraman & 4 Yll & Ön sağ & Orta & Hafif & Yok & Yok & Yok \\
\hline
\end{tabular}


Tablo 4. IV. grup, kontrol grubu topallık derecelendirmesi.

Table 4. Group IV, lameness scores in the control group.

\begin{tabular}{|c|c|c|c|c|c|c|c|c|c|c|}
\hline \multirow{2}{*}{ Sira } & \multirow{2}{*}{$\begin{array}{l}\text { Küpe no: } \\
\text { TR49 }\end{array}$} & \multirow{2}{*}{ Cinsiyet } & \multirow{2}{*}{ Irk } & \multirow{2}{*}{ Yaş } & \multirow{2}{*}{$\begin{array}{c}\text { Topallayan } \\
\text { ayak }\end{array}$} & \multicolumn{5}{|c|}{ Topallık derecesi } \\
\hline & & & & & & Uyg öncesi & 24. saat & 48. saat & 72. saat & 96. saat \\
\hline 1 & 2155423 & Dişi & Akkaraman & $4 Y_{l l}$ & Ön sağ & Şiddetli & Yok & Yok & Şiddetli & Şiddetli \\
\hline 2 & 2155435 & Dişi & Akkaraman & 4 Yll & Arka sağ & Şiddetli & Şiddetli & Şiddetli & Şiddetli & Şiddetli \\
\hline 3 & 1980994 & Dişi & Akkaraman & 3 Yll & Arka sağ & Orta & Yok & Orta & Orta & Orta \\
\hline 4 & 2155242 & Dişi & Morkaraman & 4 Yll & Ön sol & Orta & Orta & Orta & Hafif & Hafif \\
\hline 5 & 2155457 & Dişi & Akkaraman & 4 Yll & Arka sağ & Orta & Orta & Orta & Hafif & Hafif \\
\hline 6 & 2155399 & Dişi & Akkaraman & 4 Yll & Arka sol & Orta & Orta & Orta & Orta & Orta \\
\hline 7 & 561713650 & Dişi & Akkaraman & 4 Yll & Arka sağ & Orta & Orta & Yok & Hafif & Hafif \\
\hline 8 & 2155430 & Dişi & Akkaraman & 4 Yll & Ön sol & Orta & Yok & Yok & Yok & Yok \\
\hline 9 & 2155225 & Dişi & Akkaraman & 5 Yll & Ön sağ & Orta & Orta & Orta & Orta & Orta \\
\hline 10 & 2155422 & Dişi & Akkaraman & 4 Yll & Arka sağ & Şiddetli & Şiddetli & Şiddetli & Şiddetli & Şiddetli \\
\hline
\end{tabular}

Tablo 5. Piyetenli ve sağlıklı koyunların kan serumu eser element analiz sonuçları.

Table 5. Trace element analysis results in blood serum of the healthy sheep and sheep with footrot.

\begin{tabular}{|c|c|c|c|c|c|c|c|c|c|}
\hline $\begin{array}{c}\text { Numune } \\
\text { Adı } *\end{array}$ & $\begin{array}{c}\text { Bakır } \\
(\mathrm{Cu}) \\
(\mathrm{mg} / \mathrm{L})\end{array}$ & $\begin{array}{c}\text { Çinko } \\
\text { (Zn) } \\
\text { (mg/L) }\end{array}$ & $\begin{array}{c}\text { Kalsiyum } \\
\text { (Ca) } \\
\text { (mg/dl) }\end{array}$ & $\begin{array}{c}\text { Fosfor } \\
\text { (P) } \\
\text { (mg/dl) }\end{array}$ & $\begin{array}{c}\text { Numune } \\
\text { Adı } *\end{array}$ & $\begin{array}{c}\text { Bakır } \\
\text { (Cu) } \\
(\mathrm{mg} / \mathrm{L})\end{array}$ & $\begin{array}{c}\text { Çinko } \\
\text { (Zn) } \\
\text { (mg/L) }\end{array}$ & $\begin{array}{c}\text { Kalsiyum } \\
\text { (Ca) } \\
\text { (mg/dl) }\end{array}$ & $\begin{array}{c}\text { Fosfor } \\
\text { (P) } \\
\text { (mg/dl) }\end{array}$ \\
\hline $\mathrm{S} 1$ & 4.6773 & 1.6279 & 11.6 & 6.6 & $\mathrm{P} 1$ & 4.5622 & 1.6683 & 10.3 & 6.1 \\
\hline S2 & 4.0441 & 1.3256 & 11.0 & 6.6 & $\mathrm{P} 2$ & 4.9755 & 1.0369 & 10.0 & 5.0 \\
\hline S3 & 5.1665 & 0.9802 & 9.9 & 6.6 & P3 & 5.1050 & 1.1583 & 9.7 & 4.8 \\
\hline S4 & 4.6485 & 1.3796 & 10.0 & 6.5 & $\mathrm{P} 4$ & 4.4614 & 1.3121 & 9.6 & 5.5 \\
\hline S5 & 4.9866 & 1.7061 & 9.1 & 6.1 & P5 & 5.1953 & 1.0639 & 9.8 & 4.5 \\
\hline S6 & 4.4327 & 1.5118 & 10.2 & 6.3 & P6 & 4.8787 & 0.9586 & 10.1 & 4.9 \\
\hline S7 & 4.3175 & 1.5658 & 11.7 & 6.7 & P7 & 4.5765 & 0.8048 & 10.1 & 3.9 \\
\hline S8 & 4.2312 & 1.3769 & 8.8 & 7.6 & P8 & 4.9939 & 1.6213 & 9.5 & 5.2 \\
\hline S9 & 4.6053 & 1.7520 & 10.0 & 7.0 & P9 & 4.7565 & 1.4066 & 9.5 & 5.5 \\
\hline S10 & 5.5263 & 1.7439 & 10.3 & 5.0 & P10 & 4.7924 & 1.2150 & 9.7 & 5.5 \\
\hline S11 & 4.9795 & 1.2797 & 9.0 & 7.0 & P11 & 5.0370 & 1.3553 & 9.7 & 4.5 \\
\hline $\mathrm{S} 12$ & 4.3751 & 1.4309 & 8.1 & 5.5 & P12 & 5.1809 & 1.3094 & 10.4 & 6.5 \\
\hline S13 & 4.1449 & 1.5037 & 10.0 & 5.8 & P13 & 5.4255 & 1.1988 & 9.3 & 6.3 \\
\hline S14 & 4.3751 & 1.7358 & 9.3 & 6.5 & P14 & 5.6414 & 1.2150 & 9.9 & 6.1 \\
\hline S15 & 4.2024 & 1.5874 & 10.4 & 4.8 & P15 & 5.3104 & 0.9262 & 9.1 & 4.8 \\
\hline S16 & 4.2456 & 1.5805 & 9.9 & 6.6 & P16 & 5.4543 & 1.0261 & 9.1 & 5.4 \\
\hline S17 & 5.2529 & 1.6791 & 8.6 & 5.6 & P17 & 5.5694 & 1.1988 & 9.7 & 4.6 \\
\hline S18 & 4.3751 & 1.9355 & 9.6 & 4.3 & P18 & 4.9795 & 1.1718 & 9.2 & 7.0 \\
\hline S19 & 4.8356 & 1.5199 & 9.2 & 7.0 & P19 & 5.2529 & 0.9856 & 8.8 & 6.1 \\
\hline S20 & 4.1161 & 1.1124 & 11.1 & 6.6 & P20 & 5.1521 & 1.2582 & 10.0 & 5.7 \\
\hline
\end{tabular}

*S: Sağlıklı hayvanlardan alınan kan serumu numunesi, P: Piyetenli hayvanlardan alınan kan serumu numunesi. 


\section{İstatistiksel Analizler}

Çalışmanın aynı zamanda bir insidans araştırması olması sebebiyle saha ve sürü taramasının başlangıcından itibaren elde edilen bütün verilerin istatistiki değerlendirilmesi yapılmıştır. Ayrıca kandaki Ca, P, Zn ve $\mathrm{Cu}$ miktarlarının hastalıklı ve sağlam hayvanlardaki değerleri karşılaştırılarak istatistiki olarak önemli olup olmadığı tespit edilmiştir. İstatistiksel analiz olarak sayısal ve yüzde hesaplamaların yanı sıra SPSS paket programı ile t-testi ve korelasyon analizi yapılmıștır. İstatistik önem değeri $\mathrm{P}<0.05$ olarak alınmıştır.

\section{BULGULAR}

Sunulan çalışmada; sahada toplam 10604 hayvandan 6031 baş Morkaraman, 4573 baş Akkaraman irkı koyunlar incelenmiş olup, bunlardan 969 baş hayvanın piyetenli olduğu ve bunun 927 başının dişi ve 42 başının erkek olduğu saptanmıştır. Lezyonlara bağlı olarak hayvanlarda hafif, orta ve ileri derecelerde topallıklar gözlenmiștir. Lezyon nedeniyle ayakta durmakta güçlük çeken koyunların karpal eklem üzerine durarak otladıkları belirlenmiştir (Şekil 1).

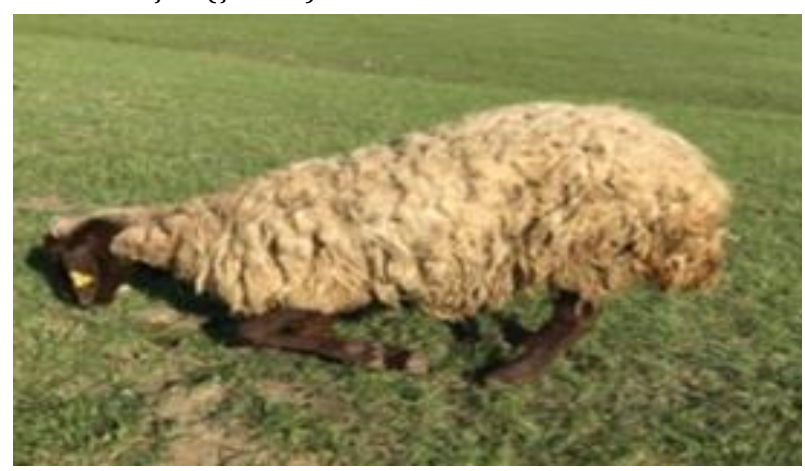

Şekil 1. Ön ayaklarında piyeten olduğu için karpal eklem üzerine duran ve otlayan koyun.

Figure 1. Sheep standing and grazing on the carpal joint due to footrot on the front legs.

Hastalıklı ayaklarda yapılan fiziksel muayene sırasında tırnak arası deride değişik büyüklükte lezyonların olduğu, derinin nekroze olduğu, zaman zaman kurumuş çamurla yaraların üzerlerinin kaplandığı, bölgeye basınç uygulayınca kabuk ve çamur örtüsünün altında biriken irinin ve akıntıların dışarıya çıktığı gözlenmiştir. Ayrıca bölgeden kötü koku geldiği, nekrotik dermatitisin yanı sıra ilerlemiş vakalarda tırnakların deformasyona uğradığı saptanmıștır (Şekil 2A-B).

Çalışmanın yapılması sırasında saha ve sürü taramalarında yetiștiricilerin bir kısmının piyetenin tedavisinde sadece ayaklardaki yarayı kapatıcı katran vb. maddeler uygulayarak iyileştirmeye çalıştıkları görülmüştür. Yetiştiricilerin büyük bir kısmının da uzun süre etkili (LALong Acting) parenteral antibiyotikleri kullandıkları ancak antibiyotik kullandıktan sonra süt ve eti belirli bir süre tüketmemeleri gerektiğini bilmedikleri, ilaç kalıntı arınma süresinden (İKAS) bihaber oldukları, durumu bilenlerin ise çok önemsemedikleri görülmüştür.

Yetiştiricilerin üretmiş oldukları bu et ve sütün İKAS beklenmeden gıda zincirine girmesi sebebiyle gıda güvenliği, halk sağlığı ve hayvan sağlığı için ciddi bir problemle karşı karşıya olduğumuz anlaşılmıștır.
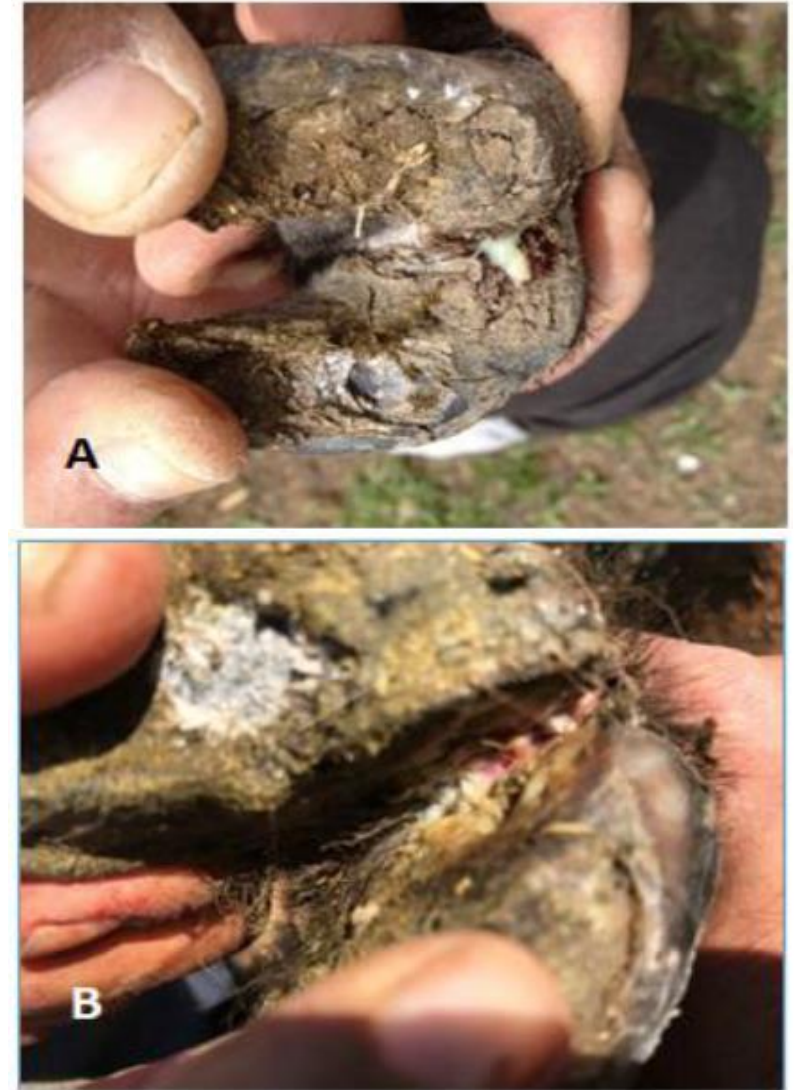

Şekil 2. A) Piyetende purulent akıntı, B) Piyetende interdigital bölgede lezyon.

Figure 2. A) Purulent discharge in footrot, B) Lesion in the interdigital area with footrot.

\section{Tedavi Bulguları}

Tablo 1'de orta ve şiddetli topallık semptomları gösteren toplam on piyetenli koyunda ilk uygulamadan 24 saat sonra \%70'inde bir iyileşme görülmüş olup, ikinci uygulamadan 24 saat sonra ise \%90'ında bir iyileşme görülmüştür. 96 saatin sonunda yapılan kontrolde $\% 90$ iyileşme oranı devam etmiş olup, iyileşen hayvanlarda nüks gözlenmemiştir. Bir vakada şiddetli derecede olan topallığın 96 saat sonunda hafif derecede topallık durumuna geldiği görülmüştür.

Tablo 2'de belirtilen tedavi gurubunda ilk uygulamadan 24 saat sonra \%40'ında bir iyileşme görülmüş olup, 48 saatin sonunda \%60 ve 96 saatin sonunda da \%60'ında bir iyileşme gözlenmiştir. Ancak tablodan da görüleceği üzere 5. ve 9. sıradaki hayvanlarda 48 saatin sonunda topallık gözlenmezken aynı hayvanların 72 ve 96 saatin sonrasında topallık semptomu gösterdikleri ve iyileşmedikleri görülmüştür.

Tablo 3'de belirtilen gruptaki hayvanlarda 48 saatin sonrasında \%10'unda bir iyileşme, 72 saatin sonrasında bu oran \%20'ye çıkmış ve 96 saatin sonrasında da farklı bir durum gözlenmemiştir.

Herhangi bir tedavi uygulanmayan Tablo 4'deki grupta 24 ve 48 saatin sonunda \%30'unda bir iyileșme hali gözlenirken 72 ve 96 saatin sonrasında sadece \%10'unda bir iyileșme olduğu görülmüștür. Bu grupta 1,3 ve 7 . sıradaki hayvanlarda 24 ve 48 saat sonrasinda kaybolan topallığın daha sonraki kontrollerde tekrar devam ettiği gözlenmiștir. 
V. grup: Așılanan koyunlarda iki-üç hafta aralıklarla yapılan kontrollerde sadece iki koçta rapel uygulamasından uzun bir süre sonra 3-4 gün süren hafif bir topallık görülmüș olup, bunun dișında yıl boyunca 230 baş hayvanın tamamında herhangi bir piyeten belirtisi görülmemiştir. Çevre köylerde piyeten hastalığından muzdarip yetiştiricilerin olduğu ve hastalığın üç ay boyunca sürülerinden çıkmadığı gözlenmiştir.

Kan serumlarındaki $\mathrm{Ca}, \mathrm{P}, \mathrm{Zn}$ ve $\mathrm{Cu}$ elementlerinin analiz sonuçları ve değerlendirilmesi Tablo 5-9'da belirtilmiștir.

\section{İstatistiksel Bulgular}

0-4 yaş dişi Morkaramanların aynı yaş dişi Akkaramanlara göre piyetene daha dayanıklı oldukları (\%7.81<\%10.64), ancak aynı yaş erkeklerde Akkaramanlar daha dayanıklı görünmekle beraber $(\% 12.50<\% 18.11)$ örnek erkek hayvan sayısının azlığı dolayısıyla tam olarak böyle bir yargıya varmanın mümkün olamayacağı söylenebilmektedir.

Yine cinsiyet ayrımı yapmaksızın 0-4 yaş aralı̆̆ı için piyeten hastalığına karşı Morkaramanların Akkaramanlardan daha dayanıklı olduğu açıkça görünmektedir $(\% 8.12<\% 10.73)$.

4 yaș üstü dișiler için Akkaramanların Morkaramanlara oranla biraz daha dayanıklı olduğu gözükmekle beraber (\%8.54<\%9.20) önemli bir fark olarak değerlendirilmemekte ve daha önce hastalığa yakalanma oranının yüksekliği ve aynı hastalık antijenine karșı vücudun bağıșıklık kazanmasının bunda etkili olduğu düşünülmektedir.

4 yaş üstü erkekler için Akkaramanlarda hasta hayvan bulunamadığından değerlendirilememiștir. $0-4$ yaş Akkaraman erkeği ile 0-4 yaş Morkaraman erkeği oranlarında Akkaramanların daha dayanıklı oldukları (\%12.50<\%18.11) görünmekle beraber, 0-4 yaş Akkaraman erkeği ile 4 yaş üstü Morkaraman erkeği oranları birbirine yakın değerde çıkmıştır (\%11.76<\%12.50). Bu durumların çalıșmaya dâhil edilen erkek hayvan sayısı azlığından kaynaklandığı düşünüldüğünden isabetli bir değerlendirme yapılamayacağı ortaya çıkmıştır.

Cinsiyet ve yaş ayrımı yapılmaksızın sadece ırk bazında yüzde oranlar değerlendirildiğinde Morkaramanların Akkaramanlara oranla piyetene daha dayanıklı oldukları görülmektedir (\%8.47<\%10.02).

Sunulan çalışma kan parametreleri yönünden değerlendirildiğinde; Tablo 6'da görüldüğü üzere bakır, çinko ve fosfor bakımından sağlıklılar ile piyetenliler arasında fark olduğu görülmektedir. Piyetenli grupta hastalığa bağlı olarak, bakır değeri artmış $(\mathrm{P}<0.001)$, çinko $(\mathrm{P}<0.001)$ ve fosfor $(\mathrm{P}<0.01)$ değeri azalmıştır.

Korelasyonun önemli olduğu parametreler, sağlıklı koyunlar açısından değerlendirildiğinde fosfor ile çinko arasında negatif bir korelasyon $(\mathrm{P}<0.05)$ olduğu anlașılmıștır. Piyetenliler açısından böyle bir korelasyondan bahsedilemeyeceği, bununla beraber genel değerlendirildiğinde ise çinko-bakır ve kalsiyum-bakır arasında negatif korelasyon $(\mathrm{P}<0.05)$ olduğu belirlenmiștir. Diğer bir ifadeyle hastalığa bağlı olarak piyetenlilerde bakır değerinde yükselme buna karșın çinko ve kalsiyum değerinde azalma görülmektedir. Sunulan çalışmada Ca ve P değerleri arasında istatistiki açıdan bir anlam bulunamamıștır (Tablo 6-9).
Tablo 6. Sağlıklı ve piyetenli koyunların biyokimyasal kan parametreleri.

Table 6. Biochemical blood parameters of healthy sheep and sheep with footrot.

\begin{tabular}{lcc}
\hline Kan Parametreleri & $\begin{array}{c}\text { Sağllklı grup } \\
(\mathbf{n = 2 0})\end{array}$ & $\begin{array}{c}\text { Piyeten grubu } \\
(\mathbf{n = 2 0 )}\end{array}$ \\
\hline Bakır (mg/L) & $4.57 \pm 0.42^{* *}$ & $5.06 \pm 0.33$ \\
Çinko (mg/L) & $1.51 \pm 0.23^{* *}$ & $1.194550 \pm 0.21$ \\
Kalsiyum (mg/dl) & $9.89 \pm 0.96$ & $9.67 \pm 0.42$ \\
Forfor (mg/dl) & $6.23 \pm 0.83^{*}$ & $5.39 \pm 0.78$ \\
\hline
\end{tabular}

Aynı satırda bulunan parametreler istatistiki olarak önemlidir. ${ }^{* *} \mathrm{P}<0.001,{ }^{*} \mathrm{P}<0.01$

Grup istatistiğine göre bakır, çinko ve fosfor bakımından sağlıklılar ile piyetenliler arasında fark olduğu görülmüștür. Piyetenli grupta hastalığa bağlı olarak, bakır değeri artmış $(\mathrm{P}<0.001)$, çinko $(\mathrm{P}<0.001)$ ve fosfor $(\mathrm{P}<0.01)$ değeri azalmıștır.

Tablo 7. Sağlıklı hayvanların kendi içinde korelasyonu tabloda gösterilmiștir.

Table 7. Correlations among healthy animals are shown in the table.

\begin{tabular}{lccc}
\hline & Bakır & Çinko & Kalsiyum \\
\hline Çinko & .093 & & \\
Kalsiyum & -.276 & -.091 & \\
Fosfor & -.110 & $-.481^{*}$ & .073 \\
\hline
\end{tabular}

$* \mathrm{P}<0.05$

Korelasyonun önemli olduğu parametreler, sağlıklılar açısından değerlendirildiğinde fosfor ile çinko arasında negatif bir korelasyon $(\mathrm{P}<0.05)$ olduğu belirlenmiștir.

Tablo 8. Piyetenli hayvanların kendi içinde korelasyonu tabloda gösterilmiștir.

Table 8. Correlations among animals with footrot are shown in the table.

\begin{tabular}{lccc}
\hline & Bakır & Çinko & Kalsiyum \\
\hline Çinko & -.233 & & \\
Kalsiyum & -.329 & .226 & \\
Fosfor & .124 & .360 & -.159 \\
\hline
\end{tabular}

Korelasyonun önemli olduğu parametreler, piyetenliler açısından değerlendirildiğinde herhangi bir korelasyon belirlenememiștir.

Tablo 9. Sağlıklı koyunlar ile piyetenli koyunların kendi içinde korelasyonu tabloda gösterilmiştir.

Table 9. The correlation between healthy sheep and sheep with footrot is shown in the table.

\begin{tabular}{lccc}
\hline & Bakır & Çinko & Kalsiyum \\
\hline Çinko & $-.358^{*}$ & & \\
Kalsiyum & $-.312^{*}$ & .088 & \\
Fosfor & -.266 & .220 & .072 \\
\hline
\end{tabular}

$* \mathrm{P}<0.05$

Korelasyonun önemli olduğu parametreler, genel değerlendirildiğinde ise çinko ile bakır ve kalsiyum ile bakır arasında negatif korelasyon $(\mathrm{P}<0.05)$ olduğu belirlenmiştir. Piyetenlilerde bakır değerinde yükselme 
buna karşın çinko ve kalsiyum değerinde azalma görülmektedir.

\section{Makroskobik Bulgular}

Koyunların ayak nekropsisinde tırnak arası deride nekrotik-ülseratif dermatitisin bulunduğu, tırnakların ise deformasyona uğradığı saptandı (Șekil 3). Bu interdigital derinin kesit yüzünde yangısal reaksiyonların tırnağın derin katmanların doğru yayıldığı, bu kısımlarda konjesyon ve ödem oluştuğu dikkati çekti (Şekil 4). Nekropsi yapılan bu koyunların iç organlarının incelenmesinde morfolojik değișiklikler belirlenmedi.

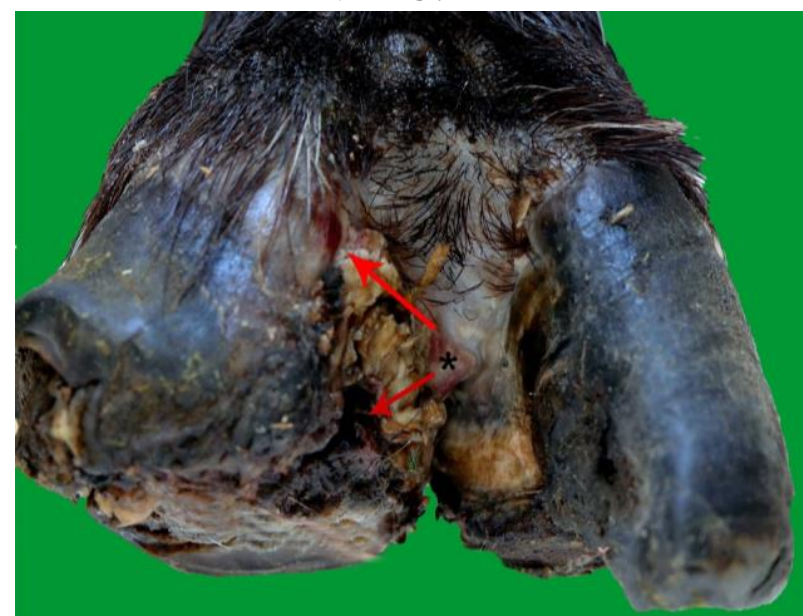

Şekil 3. İnterdigital bölgede eroziv-ülseratif lezyon $\left(^{*}\right)$ ve bunun çevresindeki bölgelerde deformasyonlar (oklar) izlenmektedir.

Figure 3. An erosive-ulcerative lesion $\left(^{*}\right)$ in the interdigital area and deformations (arrows) in the surrounding areas are observed.

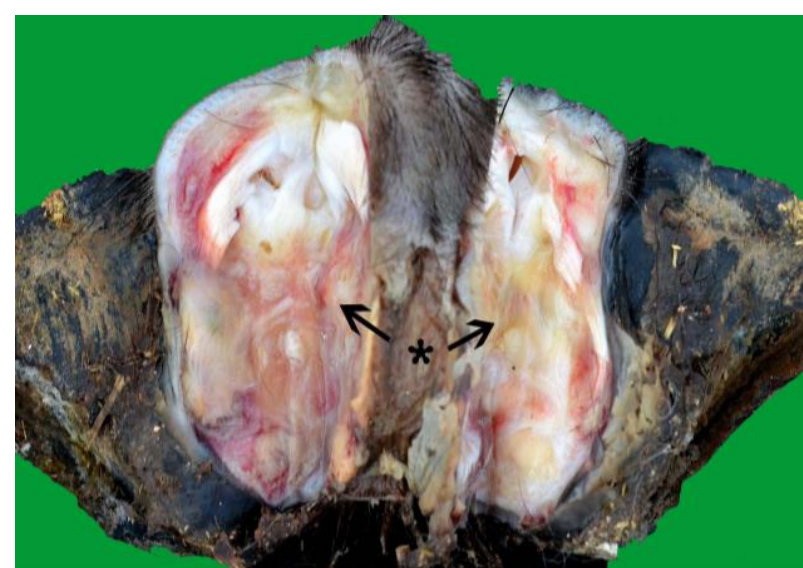

Şekil 4. Tırnağın kesit yüzünde ülserasyonlu bölgenin $\left(^{*}\right)$ çevresinde yangısal reaksiyonların bölge derisinin derin katmanlarına doğru yayıldığı, bu kısımlarda șiddetli konjesyon ve eksudat birikiminden dolayı ödemli (oklar) olduğu görülmektedir.

Figure 4. On the cross-sectional face of the nail, it is seen that the inflammatory reactions around the ulcerated area $\left({ }^{*}\right)$ spread towards the deep layers of the skin of the area, and these parts are edematous (arrows) due to severe congestion and accumulation of exudate.

\section{Mikroskobik Bulgular}

Lezyonlu ayaklardan alınan doku örneklerinin histopatolojik incelenmesinde nekrotik-ülseratif bölgeler ve çevresindeki dokularda da ödem, lökosit infiltrasyonları ve hiperemi yaygın olarak gözlenmiştir. Tırnaklar arasındaki ülserasyonların piyeten (footrot) hastalığı sonucu şekillenen lezyonlar olduğu saptanmıștır (Şekil 5).

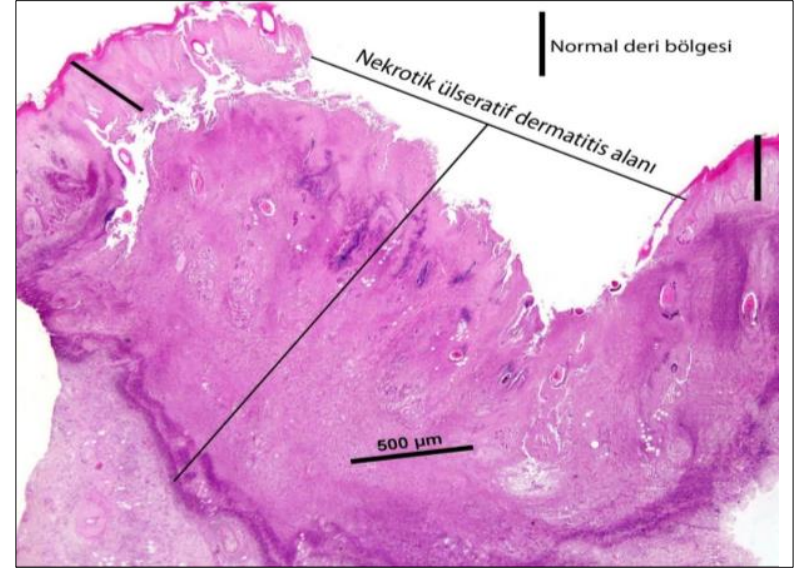

Şekil 5. Lezyonlu doku örneklerinin mikroskobik incelenmesinde kısmen normal epidermis, deri, ülserasyon alanı ve geniș koagulasyon nekrozu, nekrozun çevresinde mor renkte yoğun lökosit ve bakteri proliferasyonlarından oluşan yangısal bir hat izlenmektedir.

Figure 5. Microscopic examination of lesional tissue samples reveals an inflammatory line consisting of partially normal epidermis, skin, ulceration area and large coagulation necrosis, purple dense leukocyte and bacterial proliferation around the necrosis.

\section{TARTIŞMA ve SONUÇ}

Yaz dönemi ayları hariç yılın üç mevsiminde önemli miktarda yağış alan Muş'ta nemli ortamların olması nedeniyle özellikle küçükbaşların en önemli ayak hastalığı olan piyeten \%9.14 oranında belirlenmiştir.

Piyeten hastalığı tedavi edilmediği veya geç fark edildiği zaman sürüdeki diğer sağlam hayvanlara da bulaşmaktadır. Bölgede mera hayvancılığı yaygın olarak yapıldığından ve meralar kontamine olduğundan her yıl hastalık sürüye bulaşabilmekte, dolayısıyla koyun yetiștiriciliğinde göz ardı edilemeyecek derecede önemli gelir kaybı anlamı taşımaktadır.

Hastalığın insidansı predispoze faktörlere bağlı olarak yörelere göre farklılık göstermektedir (Bulut 1982; Egerton ve Laing 1982; Heitz 1982; Parajuli ve Goddard 1989; Tulasne ve Beguin 1982). Sürülerdeki morbiditesinin\%8-100, mortalitesinin\%40'lara çıtı̆̆ bildirilmiștir (Heitz 1982; İzci 1993; Tulasne ve Beguin 1982). Sağlıyan (2003) Elazı̆̆ bölgesinde yaptığı çalışmada piyetenin görülme oranının \%18.95 olduğunu bildirmekte olup, Bulut (1982), Doğu Anadolu Bölgesinde yaptığı bir çalıșmada hastalığın insidansını Elazığ'da \%15.4, Bingöl'de \%9.1 ve Malatya'da \%8.3 olarak tespit etmiștir. Bu çalışmada oran \%9.14 olarak tespit edilmiş olup Muş'un sınır komşusu olan Bingöl ilinin verisiyle örtüşmektedir.

Sağlıklı koyunların kan serumu $\mathrm{Zn}$ ve $\mathrm{Cu}$ düzeylerini; Altıntaş ve Fidancı (1993) $\mathrm{Zn} 0.80-1.17 \mathrm{mg} / \mathrm{L}$ ve $\mathrm{Cu} 0.58$ $1.6 \mathrm{mg} / \mathrm{L}$, Alkan (1998), Zn 0.81-1.24 mg/L ve Cu 1.13-1.43 $\mathrm{mg} / \mathrm{L}$, Belge ve ark. (1996), Zn 0.45+0.022 mg/L, Sağliyan ve ark. (2003), $\mathrm{Zn} 0.62-1.24 \mathrm{mg} / \mathrm{L}$ ve $\mathrm{Cu} 0.57-0.85 \mathrm{mg} / \mathrm{L}$, Camaș ve ark. (1997) $\mathrm{Zn} 0.25+0.044 \mathrm{mg} / \mathrm{L}$, Doğanay (1996) $\mathrm{Zn} 1.84 \mathrm{mg} / \mathrm{L}$ ve $\mathrm{Cu} 1.09 \mathrm{mg} / \mathrm{L}$, Egerton ve Laing (1978) $\mathrm{Zn} \mathrm{0.81-1.14} \mathrm{mg/L,} \mathrm{Ghosal} \mathrm{ve} \mathrm{Mathur} \mathrm{(1992)} \mathrm{Zn}$ 0.74-0.81 mg/L ve Cu 0.63-0.76 mg/L, Şahin ve ark. (2001) Zn 1.03-1.09 mg/L ve Cu 0.75-0.78 mg/L, Tiftik (1996) Zn $1.40 \mathrm{mg} / \mathrm{L}$, Kelly (1974) Cu 0.7-1.3 mg/L, Nelson ve ark. (1984) Cu 0.84-1.0 mg/L, Kaneko (1980) Cu 0.58-1.6 mg/L olarak bildirmişlerdir. 
Muş ve yöresi sağlıklı koyunlarında $1.51 \mathrm{mg} / \mathrm{L}$ olarak tespit edilen ortalama serum çinko düzeyi (Tablo 6), araştırmacılar Egerton ve Laing (1978), Tiftik (1996), Doğanay (1996), Alkan (1998) ile Sağlıyan ve ark. (2003)'nın bulgularına benzerlik göstermektedir. Çinko için tespit edilen bu ortalama değer Doğanay (1996)'ın bulgusundan düşük, Tiftik (1996)'in bulgusuna yakın, Alkan (1998), Sağliyan ve ark. (2003), Egerton ve Laing (1978), Çamaş ve ark. (1997) ile Belge ve ark. (1996)'nın bulgularından yüksek bir değerde çlkmıştır. Bu durumun hayvanların beslendiği mera ve otlakların bitki örtüsü ve toprak yapısından kaynaklandığı düşünülmektedir.

Piyetenli koyunların ortalama serum çinko düzeylerini Sağlıyan ve ark. (2003), 0.47 mg/L, Alkan ve Yavru (2000), $0.68 \mathrm{mg} / \mathrm{L}$, Belge ve ark. (1996), $0.23 \mathrm{mg} / \mathrm{L}$, Egerton ve Laing (1978), $0.93 \mathrm{mg} / \mathrm{L}$ olarak bulmuşlardır. Araștırıcılardan Ersoy ve Bayşu (1986),Ghosal ve Mathur (1992), Belge ve ark. (1996) ile Sağllyan ve ark. (2003), serum çinko düzeyinin $0.4 \mathrm{mg} / \mathrm{L}$ 'nin altına düşmesinin çinko yetmezliğine bağlı semptomların görülmesine neden olacağını vurgulamışlardır. Serum bakır düzeyinin ise 0.5 mg/L'nin altında olması Serpek (1983) ve Doğanay (1996) tarafından hipokuprozis sınırı olarak belirtilmiștir.

Muş ve yöresi piyetenli koyunlarında ise $1.19 \mathrm{mg} / \mathrm{L}$ olarak tespit edilen ortalama serum çinko düzeyi (Tablo 6), araștırmacılar Ersoy ve Bayşu (1986), Ghosal ve Mathur (1992), Belge ve ark. (1996) ile Sağlıyan ve ark. (2003)'nın noksanlık sınırı olarak belirttikleri $0.4 \mathrm{mg} / \mathrm{L}$ 'nin üstünde olması Muş ve yöresi koyunlarında sekunder çinko yetmezliğinden söz edilemeyeceğini göstermektedir.

Sağlıklı koyunların Zn ortalaması (1.51 mg/L) ile piyetenli koyunların $\mathrm{Zn}$ ortalaması (1.19 mg/L) noksanlık sınırının üzerinde olmasına rağmen piyetenlilerde önemli bir düşüşün olduğu gözlenmiştir. Bu sonuç araştırıcılar Egerton ve Laing (1978), İzci (1993), İzci ve ark. (1994),Whittington ve ark. (1994), Grono-Thomas (1997), Belge ve ark. (1996), Alkan ve Yavru (2000) ile Sertkaya ve Şındak (2004)'ın sağlıklı koyunlara göre piyetenli koyunların serum çinko düzeylerinin daha düşük olduğu görüşleriyle benzerlik göstermektedir. Belge ve ark. (1996), hastalığın profilaksisinde ve sağaltımında çinkonun göz önünde bulundurulması gerektiğini ifade ederek, çinko yetmezliğinin yara iyileșmesinde önemli rol oynayan kollajenin sentezinde azalma ve kollajen liflerinin çapraz bağlanmasında anormalliklere neden olduğunu saptamışlardır. Kollajenin polisakkarit ve muko proteinlerle birleșerek güçlü bir yapı oluşturduğunu böylece yara dudakları arasında sağlam bir bağlantı kurduğunu vurgulamışlardır.

Araştırmacılardan Ası (1983), Bremmer (1970), Cousins (1989), Ersoy ve Bayșu (1986), Özgen (1970) ile Simenson (1980) sağlıklı koyunların serum Ca değerini 9.3-11.7 $\mathrm{mg} / \mathrm{dl}, \quad P$ değerini ise $4.0-7.3 \mathrm{mg} / \mathrm{dl}$ aralığında bildirmişlerdir.

Sunulan çalıșmada Ca ve $\mathrm{P}$ değerleri arasında istatistiki açıdan bir anlam bulunamamıștır. Ancak piyetenli koyunlarda Ca değerindeki azalma istatistiki olarak tespit edilmiştir $(\mathrm{P}<0.05)$. Çalışmada sağlıklı ve piyetenli koyunların serum Ca değerleri sırasıyla $9.89+0.96 \mathrm{mg} / \mathrm{dl}$ ile $9.67+0.42 \mathrm{mg} / \mathrm{dl}$ olarak birbirine yakın değerlerde bulunmuştur. Piyetenli hayvanların serum Ca düzeyinde görülen azalma Belge ve ark. (1996)'nın bulgularıla benzerlik göstermektedir $(9.47+0.57 \mathrm{mg} / \mathrm{dl}$ ve $8.96+0.26$ $\mathrm{mg} / \mathrm{dl}$ ). Ancak her iki düzey de koyunlar için bildirilen 9.3$11.7 \mathrm{mg} / \mathrm{dl}$ serum Ca düzeyi sınırları içerisinde kaldığından herhangi bir noksanlıktan söz edilemeyeceği değerlendirilmiştir.
Muș ve yöresinde gerçekleștirilen bu çalıșmada koyunların kan serumlarında çinko yetersizliği tespit edilmemiştir. Ancak çinkonun özellikle yara iyileşmesinde, deri bütünlüğünün sağlanmasında ve kollajen liflerinin sağlam bağlanmasında çok önemli fonksiyonu bulunmaktadır. Bu sebeple toprakları, çayır-meraları çinkodan fakir ve rasyonlarında çinko ilavesi olmadan beslenen hayvanlarda çinko yetmezliğine bağlı piyetene karşı duyarlılık oluşacağı ve hastalık görülebileceğinden sağaltım seçeneklerinden biri olarak yemlere çinko ilavesinin yararlı olacağı kanısına varılmıştır.

Whittington (1995), piyetenin sağaltımında antibiyotiklerin etkili olabilmesi için asgari 18 saat kadar terapötik düzeyde kalması gerektiğini, bu nedenle uzun süreli antibiyotiklerin hastalığın tedavisi amacıyla kullanılması gerektiğini ifade etmektedir.

Casey ve Martin (1988), penisilin-streptomisin kombinasyonunun intramüsküler uygulanması ve \%10'luk $\mathrm{CuSO}_{4}$ solüsyonunun banyo şeklinde uygulaması ile üç ay içinde iyileșme elde edilebileceğini, Gönül ve ark. (2001), penisilin-streptomisin kombinasyonunun parenteral, $\% 5$ 'lik bakır sülfat $\left(\mathrm{CuSO}_{4}\right)$ solüsyonunun banyo șeklinde uygulanmasıyla \%92, Bruere ve West (1993) ise penisilinstreptomisin kombinasyonu ile birlikte \%10'luk ZnSO4 banyosunda $5 \mathrm{dk}$. bekleterek yaptıkları uygulamalarda \%90 başarılı olduklarını bildirmektedirler.

Çalışmamızdaki Ceftiofur+Fluniksin-meglumin gurubunda \%90 oranında iyileșme başarısı elde edilmiștir. Ayrıca sütlerin imha edilmesine gerek kalmaması çok avantajlı bir sağaltım seçeneği olarak görülmüştür.

Yarsan (2013); hayvansal gıdalardaki kalıntıların giderek artan global bir sorun olduğunu ve hayvansal gidalarda veteriner ilaç kalıntılarından kaynaklanabilecek doku ve organlara olan etkileri, antibakteriyel direnç ve bağışıklık sisteminin etkilenmesi gibi riskler konusunda yetiştiricinin ve tüketicinin bilinçlendirilmesi ve bilgilendirilmesi gerektiğini vurgulamaktadır. Piyeten hastalığının tedavi sürecinde süte geçen antibiyotikler kullanılırsa ilaca göre değișmekle beraber 12-24 sağım boyunca sütün insan gıdası olarak kullanılmaması gerekmektedir. Çalışmamız sırasında yetiștiricilerden aldığımız bilgiye göre daha önceki tedavi girișimlerinde toplamda ciddi miktarda gelir kaybına neden olduğu için sütlerin imha edilmesine sıcak bakmadıkları belirlenmiştir.

Odabaşığlu (1983), Morkaraman koyunların laktasyon süt verimlerinin $92.0 \mathrm{~kg}$, laktasyon süresinin 167.2 gün olduğunu, Akkaramanların ise süt veriminin $73.6 \mathrm{~kg}$ ve laktasyon süresinin 146.9 gün olduğunu belirtmiștir. Dolayısıyla yetiştiriciler için süt, son derece kıymetli bir gelir kaynağı olmaktadır. Bu bilgiler ışığında çalışmada oluşturulan bir grupta yetiştiricilerin özellikle sütü gönül rahatlığıyla kullanmaları ve sütün heba olmasından kaynaklı zararlarını minimize etmek için, süte geçmeyen Ceftiofur ile yangı giderici (fluniksin-meglumin) ajanla sağaltım girișimi yapılmıș ve \%90 oranında iyileșme elde edilmiş ve sonuçlar yetiştiricilerle paylaşılmıştır.

Karslı ve Elma (2014) da tek bașına antiseptik olarak kullandıkları çinko sülfat $\left(\mathrm{ZnSO}_{4}\right)$ ayak banyosu uygulamasının tedavide yetersiz olduğunu fakat, parenteral spiramisin ve vitamin E uygulamasıyla birlikte çinko sülfat $\left(\mathrm{ZnSO}_{4}\right)$ ayak banyosu uygulamasının tedavide daha etkili olduğunu belirtmişlerdir.

Çalışmamızda \%10'luk bakır sülfat $\left(\mathrm{CuSO}_{4}\right)$ solüsyonunun (grup III) banyo şeklinde uygulanmasıyla elde edilen \%20 oranındaki bașarının harcanan emek, zaman ve masraflar göz önüne alındığında hastalığı tedavi etmede yeterli olmadığı ve kontrol grubuyla (grup IV) arasında önemsiz 
bir fark olduğu (\%10) tarafımızca da belirlenmiștir. Ayrıca olușturduğumuz bir bașka grupta (grup II) hayvanlara $\% 10^{\prime}$ luk $\mathrm{CuSO}_{4}+$ Fluniksin-meglumin uygulanmasiyla 96 saatin sonunda \%60 başarı elde edilmiş olsa da sonuçlarımız tarafımızca yetersiz bulunmuştur.

Parenteral antibiyotik destekli yapılan sağaltımda, süte geçmeyen Ceftiofur'un, yangı giderici bir ilaçla beraber kullanıldı̆̆ında başarı yüzdesinin (\%90) yüksek olması, 12 uygulama ile hastalığı kısa sürede tedavi etme yetkinliği ve yetiștiriciler tarafından rahatlıkla temini ve uygulanabilmesi yönleriyle piyetenin tedavisinde yetiştiricilere birçok yönden fayda sağlayacağı kanaati oluşmuştur. Antibiyotik destekli sağaltımın başarı yüzdesi belirtilen literatür verileriyle de uygunluk göstermektedir (Bruere ve West 1993; Casey ve Martin 1988; Gönül ve ark. 2001; Whittington 1995).

Lewis ve ark. (1989) 223 koyunda yapmış oldukları aşı uygulamasının ilk yılında piyetenin insidansını \%61, ikinci yılda ise $\% 45$ oranında düşürdüklerini, enfeksiyona maruz kalan koyunlarda ise yapılan aşılamanın re-enfeksiyonları \%92 oranında azalttığını belirtmişlerdir. Glenn ve ark. (1985) \%83, Bulgin ve ark. (1986) ise \%69 gibi oranlarda aşının piyetenin insidansını düşürdüğünden bahsetmektedirler.

Çalışmamızın V. grubunda 230 sağlıklı koyuna hastalıktan korunmak amaciyla Bacteroides nodosus'un 10 suşunu içeren yağlı adjuvanlı sıvı aşı uygulanmıştır. Bunlardan 228 baș koyunda bir yll boyunca herhangi bir piyeten belirtisi görülmemiş olup, sadece iki koçta piyeten şekillenmiştir.

Așıdan elde edilen sonuçların; aşılama aralığı, yaș, ırk, aşı suşu, ayak bakımı, tırnakların kesilmesi, ayak banyosu yapılması ve bireysel faktörler gibi birçok etkenden dolayı değișkenlik gösterdiği belirtilmektedir (Bulgin ve ark.1986; Glenn ve ark.1985; Lewis ve ark. 1989). Bu çalıșmada kullanılan așı sadece Bakteroides nodosus'a karșı etkili olduğundan iki koçta tam etki etmemesi hastalığın Fusobacterium necrophorum, bireysel faktörler veya bölgesel bir suștan kaynaklı olduğunu düșündürmektedir.

Avki ve ark. (2004)'nın da belirttiği gibi aşı uygulamasından elde edilen başarının, aşının bölgesel suşlardan hazırlanmasıyla daha da artacağı düşünülmekle beraber, Lewis ve ark. (1989)'nın sadece enfekte koyunlarda aşı uygulamasının hem tedavi edici hem de reenfeksiyonlara karșı korumada \%92 oranında bașarı elde etmeleri daha etkili ve daha düşük maliyetli olduğu için değerlendirilmesi gerektiği kanaati oluşmuștur.

Çalışmada ulașılan sonuçlar şöyledir; Morkaraman ırkının Akkaraman ırka göre daha dirençli olduğunun belirlendiği bu çalışmada piyeten hastalığının \%9.14'lük bir oranda ilkbahar ve sonbaharda sürülerde bulunduğu ve bunun et, süt, yapağı gibi verim kayıplarının yanı sıra, hastalığın tedavisi için veteriner hekim ve ilaç masraflarıyla beraber yetiştiriciye ciddi bir külfet oluşturduğu görülmüștür.

Hastalığın tedavisinde özellikle süte geçmeyen parenteral antibiyotiklerin kullanılması gıda güvenliği, gıda hijyeni, insan sağlığı ve hayvan sağlığı bakımından büyük önem arz etmektedir. Bu amaçla çalışmada kullanılan Ceftiofur etken maddeli preparat ile yangı giderici Fluniksin-meglumin'in başarı yüzdesinin yüksek olması, sadece hasta hayvanlarda uygulanması, daha az emek-zaman-masraf gerektirmesi, tedarik ve uygulamasının kolay ve pratik olması gibi nedenlerle yetiștiriciler tarafından arazi şartlarında, otlakta ve merada rahatlıkla uygulayabilecekleri kararına varılmıștır.

\section{ÇIKAR ÇATIŞMASI}

Yazarlar, çıkar çatışması olmadığını beyan eder.

\section{TEŞEKKÜR}

Selçuk 3. Uluslararası Uygulamalı Bilimler Kongresinde sözlü olarak sunulmuş, kongre kitabına özet metin olarak basılmıştır.

\section{YAZAR KATKILARI}

Fikir/Kavram: FY, MG

Tasarım: MG

Denetleme/Danıșmanlık: FY, MG

Veri Toplama ve/veya İșleme: FY, MG

Analiz ve/veya Yorum: FY, MG

Kaynak Taraması: FY, MG

Makalenin Yazımı: FY, MG

Eleştirel İnceleme: FY, MG

\section{KAYNAKLAR}

Alkan F (1998). Konya Bölgesindeki Koyunlarda Görülen Piyeten'in Etiyolojisinde Çinko ve Bakırın Rolü. Doktora Tezi, Selçuk Üniversitesi Sağlık Bilimleri Enstitüsü, Konya.

Alkan F, Yavru N (2000). The role of copper and zinc in the etiology of foot rot of sheep in Konya region of Turkey. Isr J Vet Med, 56 (1), 48-52.

Altıntaş A, Fidancı UR (1993). Evcil hayvanlarda ve insanda kanın biyokimyasal normal değerleri. Ankara Üniv Vet Fak Derg, 40 (2), 17386.

Avki S, Temizsoylu D, Yiğitarslan K (2004). Burdur yöresi koyunlarında ayak hastalıklarının dağılımı ve çevresel faktörler yönünden değerlendirilmesi. Türk Vet Cer Derg, 10(1-2), 5-12.

Bagley CV (1998). Sheep lameness In: The Merck Veterinary Manuel. Asello SE (Ed), 850-55, National Publishing İnc, Philadelphia,

Belge A, Bakır B, Bildik A, Yur F (1996). Piyetende kan kalsiyum, Fosfor ve Çinko düzeyleri üzerine bir araștırma. YYÜ Vet Cer Derg, 2 (1), 11-5.

Bremmer I (1970). Zinc Copper and Manganase in the Alimentary Tract of Sheep. BrJ Nutr, 24, 769-83.

Bruere AN, West DM (1993). Foot diseases and lameness in the sheep. In: Healt disease and production. Found. Vet Cont Ed, 224-30, Palmerston North, New Zealand.

Bulgin MS, Lincoln SD, Lane VM, Matlock M (1986). Comparison of treatment methods for the control of contagious ovine foot rot. JAVMA, 189(2), 194-6.

Bulut S (1982). Elazığ ve Yöresi Koyun ve Keçilerde görülen piyetenin etiyoloji, klinik seyir, epidemiyolojisi ile sağıtımlarının karşılaştırılmalı araştırması. Doktora Tezi, Fırat Üniversitesi Sağlık Bilimleri Enstitüsü. Elazı̆̆.

Casey RH, Martin PA (1988). Effect of footroting of sheep affected with footrot on response to zinc sulphate/sodiumlauryl sulphate foot bathing treatment. Aust Vet Journal, 65(5), 258-9.

Cousins RJ (1989). The oritical and Practical Aspects of Zinc up take and Absorption In: Mineral Absorption in the Monogastric GI Tract. Advances in Experimental Medicine and Biology, Dintzis FR; Laszlo JA (Eds), 249, Springer, Boston.

Camaș H, Bildik A, Gülser F (1997). Toprak, bitki ve koyunların kanında çinko miktarlarının araştırılması. Ulusal Çinko Kongresi, Eskişehir, Türkiye.

Doğanay S (1996). İzmir bölgesi koyunlarında kan serum bakır (Cu), demir (Fe), total demir bağlama kapasitesi (TDBK) ve çinko (Zn) düzeylerinin araştırılması. Doktora Tezi, Selçuk Üniversitesi, Sağlık Bilimleri Enstitüsü, Konya.

Egerton JR, Laing EA (1978). Bacterial infections in the aetiology of foot disease of ruminants. In: The second symposium on Bovine Digital Disease, Sakara, Sweden.

Egerton JR, Laing EA (1982). Comparison of bacteroides nodosus infection in sheep and cattle. In: Fourth international symposium on Disorders of Ruminant Digit, Maisons-Alfort, Paris.

Ersoy E, Bayşu N (1986). Biyokimya. Ankara Üniversitesi, Veteriner Fakültesi Yayınevi, Ankara.

Ghosal AK, Mathur GN (1992). Zinc copper and iron contents of blood serum of cattle-sheep in semi-aridtract of rajasthan. Indıan J Anım Scl, 62(5), 441-2. 
Glenn J, Carpenter TE, Hird DW (1985). A field trial to assess the the rapeuti can dprophylactic effect of a footrot vaccine in sheep. J Am Vet Med Assoc, 187, 1009.

Gönül R, Or ME, Dodurka HT(2001). Koyunlarda piyeten hastalığının saha koşullarında penisilin+streptomisin kombinasyonu ve/veya bakır sülfat ayak banyosu ile tedavisi. İst Üniv Vet Fak Derg, 27 (1), 171-7.

Grono-Thomas R (1997). Virülant footrot in sheep. Vet Rec, 141(1), 26-7.

Heitz F (1982). Control on Footrot in Sheep. In: Fourth international symposium on Disorders of Ruminant Digit, Maisons-Alfort, France.

İzci C (1993). Koyunların önemli bir ayak hastalığı; Piyeten. Hasad, 94, 268.

İzci C, Koç Y, Avki S, Kul M (1994). Konya bölgesi koyunlarında görülen extremite ve ayak hastalıklarının klinik ve radyolojik olarak değerlendirilmesi. Vet Bil Derg, 10(1-2), 16-21.

Kaneko JJ (1980). Clinical Biochemistry of Domestic Animals. Academic Press, London.

Karslı B, Elma E (2014). Koyunlarda Piyeten Hastalığında Farklı Tedavi Yöntemlerinin Etkinliğinin Değerlendirilmesi. 14. Ulusal Veteriner Cerrahi Kongresi, Antalya, Türkiye.

Kelly WR (1974). Veterinary Clinical Diagnosis. Bailliere Tindall, London.

Lewis RD, Meyer HH, Gradin JL, Smith AW (1989). Effectiveness of Vaccination in Controlling Ovine Footrot. J Animal Sci, 67, 1160-6.

Nelson DR, Wolff WA, Blodgett DJ, Luecke B, Ely RW, Zachary JF (1984). Zinc deficiency in sheep and goats: Tree field cases. JAVMA, 184(12), 1480-5.

Odabașığlu F (1983). Morkaraman, Akkaraman ve İvesi Koyunlarının Süt Verim Özelliklerinin Karșılaștırılması. Doktora Tezi, Fırat Üniversites Sağlık Bilimleri Enstitüsü, Elazığ.

Özgen H (1970). Hayvan Beslemede Organik ve Anorganik Besin Maddeleri ve Vitaminler. Ankara Üniversitesi Veteriner Fakültesi Yayınevi, Ankara.
Parajuli B, Goddard PJA (1989). Comparison of the efficacy of foot bath scontaining formalinor zincs ulphate in treating ovine footrot under field conditions. Br Vet J, 145, 467-72.

Sağlıyan A, Güney C, Koparır M (2003). Elazığ bölgesinde koyunlarda görülen Piyeten'in etiyolojisinde çinko ve bakırın rolü. Vet Cer Derg, 9(1-2), 11-6.

Sağlıyan A (2003). Elazığ bölgesi koyunlarında görülen ayak hastalıklarının klinik olarak değerlendirilmesi. FÜ Sağlık Bilimleri Dergisi, 17(1), 39-44.

Samsar E, Akın F ve Anteplioğlu H (1996). Klinik Tanı Yöntemleri ve Genel Cerrahi. Tamer Matbaacilık, Ankara.

Sertkaya H, Şındak N (2004). Şanlıurfa'nın Birecik İlçesi ve köylerinde koyun piyetenin insidansı ve iki ayrı ilaç kombinasyonu ile sağaltımı. Vet Cer Derg, 10(1-2), 48-54.

Simenson MG (1980). Calcium, Phosphorus and Magnesium Metabolism. In; Clinical Biochemistry of Domestic Animals, Kaneko JJ (Ed), Academic Press, İnc.

Şahin T, Çimtay İ, Aksoy G (2001). Pikalı ve sağlıklı kuzuların bazı biyokimyasal parametreleri üzerine araștırmalar. Türk J Vet Anim Sci, 25(4), 603-6.

Tiftik AM (1996). Klinik Biyokimya. Mimoza Yayınları, Konya.

Tulasne JJ andBeguin JC (1982). Ovinefootrot. In: Fourth İnternational symposium on Disorders of Ruminants Digit, Maisons-Alfort, France.

Whittington RJ (1995). Obsencations on the indirect transmission of VFR in sheep yards and its spread in sheep on unimproved pasture. Aust Vet Journal, 4, 72, 132-4.

Whittington RJ, Saunders VF, Moser EK (1994). Antigens for serologial diagnos of ovine footrot. Veterinary Mikrobiology, 54, 255-74.

Yarsan E (2013). Hayvansal Gıdalarda Veteriner İlaç Kalıntıları. Uluslararası 2. Helal ve Sağlıklı Gıda Kongresi, Konya, Türkiye.

Yavru N, Özkan K, Elma E (1989). Ayak hastalıkları ve ortopedi. Basım Ofset Matbaası, Ankara 